\title{
Study on Action Research: Improving Speaking Competence in English Language Through Roles in A Drama
}

\author{
Rita Sutjiati, Tri Wahyu Retno Ningsih, Suci Budiwaty \\ Universitas Gunadarma, Jakarta, Indonesia \\ ritadjohan@staff.gunadarma.ac.id, twahyurn@gmail.com, suci_budiwaty@gmail.com
}

\begin{abstract}
The purpose of the study is to obtain empirical data on the improved competence in English language through the roles in a drama. This research is an action research, meaning, an activity to improve performance between the lecturer and the student. An action research has different characteristics such as situational, contextual, collaborative, self-reflective, evaluative set and flexible ones. This study includes qualitative and quantitative measures. In a qualitative manner, the student is trained to recognise his problems, and the lecturer helps to analyse problems. The student is then trained to solve his own problems and to plan what he is going to do. The qualitative result of the study is that the student's speaking competence can be improved through applications in the drama roles. The applications or method of learning may improve student's confidence in learning English language.
\end{abstract}

Keyword: action research, roles in drama, speaking competence

\section{INTRODUCTION}

The main problems faced by teachers are teaching material associated with literature genre, speaking in a large class, little time, limited teaching aids, and also the lower motivation of students in speaking and arguing in the English language. With a total number of 45 students in one class and two or three hours per week, it is almost impossible to create an effective individual teacher-student interaction. Yet, we know that an interactive and communicative teaching is largely influential in mastering the speaking skill to the student rather than simply writing and speaking abilities. The student, however, needs a good speaking ability.

Many learning methods were born from a drama. The most important of them is called Process Drama and is about learning foreign languages through theater. Drama contributed to the view of speaking skill and they have shown the profit of possessing the kind of skills. Drama is a process and does not need the culminate in any sort production or performance. Lambirth (2005) defines this as process drama which is not audience centered but student centered. One way of structuring drama is to allow students to explore resources before structuring an activity and then to allow further free play.

Speaking is the productive skill in the oral mode. It is like the other skills, more complicated than it seems at first and involves more than just pronouncing words (Orwig, 1999). It is producing systematic verbal utterances to convey the meaning. The utterance is simply things people say. It is the act, utterance, or discourse of a person who speaks.
Speaking is the action of passing on information or expressing your thought and feelings in spoken language. The term is also used in reference to the act or process of delivering speeches or lectures. Speaking is an interactive process of constructing meaning that involves producing and receiving and processing information (Brown, 1994; Burns \&Joyce., 1997). A speaker's skills and speech habits have an impact on the success of any exchange (Van Duzer, 1997). Speaking requires that learners not only know how to produce specific points of language such as grammar, pronunciation, or vocabulary (linguistic competence) but sociolinguistic competence. In sociolinguistics, speaking or the speaking model is a model socio-linguistic study (represented as a mnemonic) developed by Dell Hymes. It is a tool to assist the identification and labeling of a component of linguistic interaction that was driven by his view that, in order to speak a language correctly, one needs not only to learns its vocabulary and grammar, but also the context in which words are used. Hymes (1974), p.53-62.

Hymes (1972) in Vakili (2012) proposed the concept of communicative competence' which is underlying knowledge of the rules speaking. Hymes offers the example of speech situation, a conversation during speech event and speech act. Hymes (1974) also proposed that these speech events have components that should be taken into account to produce a satisfactory description of any particular speech be relevant. He offers the mnemonic device of SPEAKING grid as a heuristic for the various factors he deems to be relevant. The factors are setting, participants, ends, act sequences, key, instrumentalities, and genre.

Speaking and writing are productive skills. According to Lakhpin (2014), active speaking is the release of inner motives, suggestions, and perceptions with an effective use of gestures, mime, signs, pantomimes and voice conveying a chosen message live to a listener (audience). This communication does not always have to be live or face to face, but it can be through other kinds of media. Active speaking is the action of conveying information or expression one's feelings in speech (Oxford English Dictionary). Active speaking is the process of directing conversation on a specific agenda by asking a question and through the use of suggestive reasoning (Terry Marsh, 2009 in Lakhpin, 2014). Some ways that can demonstrate active speaking, i.e. respond quickly, the tone of voice, speak clearly and concisely, provide progress 
reports, summarize the resolution, and end a positive note (www. mikundan.com).

Proposing drama as a teaching model requires a thorough consideration and elaboration. Teaching drama may be seen similar to teaching other subjects. However, in this case, drama can be positioned as either teaching materials or as a teaching model for the Faculty of letters. In the process of teaching drama, imagination and creativity are firmly rooted in play (Moyles, 1989) and playfulness remains part of the creativity process throughout life. Play promotes the flexibility and problem-solving skills that are needed to be creativity. Those three aspects are (1) interest developmentally, consisting of components as appropriate content, ideas, concepts, themes, values, and challenge. At this stage, the main aim of the course is to create interesting concepts in teaching, (2) affect (affective meaning) is a dimension related to the reactions or feelings of listeners or readers on a literary work or drama, (3) the structure, which is associated with the choices and decisions, how to make a meaningful form of teaching in the field of drama or literary work.

The study will discuss three important points, namely, (1) What are the general impacts of drama activity to the student?; (2) What area of language mastering is improved through a drama method?; (3) Whether the student's perception of the effects of drama in the English language is consistent with the real results of learning? To answer the three points above, a research is designed.

\section{RESEARCH METHOD}

The research involves a number of steps by determining the students' group who participates in the research consisting of the second year students. The group was tested based on their English ability through drama roles. The setting is in the theater laboratory.

The participant. The pretest is conducted to learn their initial competence level in the English language to assess their initial perspective of the literary genre course and their English language. The difference on perspective and perception on the students learning is observed in this group. The pre- test is conducted through interviews with these two groups. The final test is conducted at the end of the semester when the drama is performed through assessments by other teachers not directly involved in the learning process.

The student as the subject of research is assigned to write the drama material (scenario) to learn and to perform during one semester in the period of learning and teaching session. At the end of the term, the difference of teaching learning impacts on the two groups is analysed by comparing the performance and perspective on the English drama teaching.

\section{DATA ANALYSIS AND DISCUSSION}

To obtain proper reliability figure, the writer conducts an item discrimination test. Azwar (2013) says the discrimination means how far an item is able to distinguish between individuals or a group of individuals who own or do not own the attributes being measured. Azwar (2013) say that index of item discriminating power means an indicator of harmony or consistency among item functions with the overall scale function known as total item consistency. It is conducted by choosing good items and discarding bad items so that the scale owns high-reliability figures. The item discriminating power stipulated in the research is 0.3 in following Azwar's statement.

Therefore, to test reliability or item discriminating power, Alpha Cronbach analysis and item-total correlation with the assistance of SPSS Statistics Version 20 are used. The coefficient of reliability is expected to be 0.831 dan coefficient of item discriminating power ranges from 0.459 to 0.635 . This shows that the measuring tool used in the research is fairly reliable or trustworthy.

\section{MEASURER'S RELIABILITY}

To get the good numeral reliability; the writer used test of item's discrimination. Azwar (2013) said that items of discrimination effort or different effort were how far an item could differentiate between the individual and individual group who had or did not have a measurable attribute. Furthermore, Azwar (2013) said that index of item's discrimination effort was the indicator of harmony or consistency between items' functions and total item's consistency. It was done for choosing a good item and throwing away the bad one to have high reliability of the scale. Discrimination effort of the item that had been fulfilled in this research was 0.3 based on Azwar's words (2013). Then, to test the reliability and discrimination's effort of the item, the data collector would use the analysis of Alpha Cronbach and ItemTotal Correlation technique by SPSS Statistics Version 20 program. The result that had been got for reliability coefficient was 0.831 and coefficient of item's discrimination effort that moved from 0.459 to 0.635 . it showed that the measure of this research was reliable enough or trusted.

According to the description result of research data, it can be outlined about the category of research's subjects. The subject categorization that was used in this research was according to the ratio hypothetic mean and empiric mean. The number of empiric mean that was found was 28.4. The result of the descriptive analysis is that the respondent shows students' average knowledge on dramaturgy through performances is high. The component of dramaturgy can be analysed as for how far the students understand dramaturgy through performing a drama in English language. The result of descriptive analysis of respondent per dimension shows that the average student has a high understanding on each dramaturgy component through a drama performance.

The qualitative test informs that drama activity is observed positively by the subject. The qualitative analysis results are as follows:

1. The students understand that they have created a better interaction with their classmates after applying the types of drama activity from time to time and their ability to learn English improves. 
2. The students understand that applying the type of drama activity in an active manner can help recall the English language lesson learned previously.

3. The students understand that applying the type of drama activity is an efficient way in the English language learning process.

4. The students understand that type of interaction among classmates in the drama activity is able to influence their English language learning.

5. The students understand that beside application of the type of drama activity, there is a need to see more how much information in the English language is influential to their English language learning.

6. The students consider the need to seek information in English language does not help their English learning process at all.

Based on the observation, there are some differences

in a number of aspects,i.e.

1. The interaction level between teachers and students affects learning.

2. The ability of students in assessing their own ability in listening to and speaking in English.

Based on the observation above, it is obvious that speaking ability in drama is performed positively by the subjects, and the students understand that : (a) they are able to interact better with their classmates; (b) the motivation in learning English language improves; (c) the drama activity has helped them recall the English lessons learned previously; (d) the drama activity is largely efficient for learning English language; (e) interaction among classmates has been positively influencing the process of learning English language. By using their own drama scripts, there are some following differences: (a) interaction between teachers and students are seen as influencing learning process of subjects, and (b) the subjects are aware that they have made some progress in listening and speaking in English language.

The significant results are obtained as students are communicating and interacting actively with teachers in discussing obstacles faced during preparing the drama scenario. Students are also given freedom to use any type of language they consider relevant to the communication objectives in drama. In other words, the language learning is designed by the students themselves, not offered to them. A drama as a concrete expression of performance they have designed is also an appropriate place to motivate students to practice their listening and speaking to teachers or peer students. It implies that learning model through a drama is more useful when positive cooperation among students takes place as well as the interaction between teachers and students does.

\section{CONCLUSION}

The study investigates effects and uses of two types of drama activity and compares contribution on the activity on English language learning. The results of the study reveal that types of drama activity: (a) have a positive influence in the interaction among students; (b) are positively influential to the atmosphere of English language learning; (c) facilitate students in strengthening their memory of what has been learned previously. The drama activity is considered good by the two groups of students and even has a significant result on the test group who has created their own drama scripts.

\section{REFERENCES}

Azwar, S. (2012). Reliabilitas dan validitas. Jogjakarta: Pustaka Pelajar.

Bailey, K.M. \& Savage, L (1994). New ways in teaching speaking. Alexandria, VA: Teachers of English to Speakers of Other Languages.

Brown, H. D. (2001). Teaching by Principles an Interactive Approach to Language Pedagogy. New York: Addison Wesley Longman, Inc.

Burns, A. \& Joyce, H. (1997). Focusing on Speaking. Sydney: National Centre for English Language Teaching and Research.

Carter, R. \& McCarthy, M (1995). Grammar and Spoken Language. Applied Linguistics, 16 (2), 141-158.

Florez, M. A. C. (1999). Improving adults English language learners speaking skills. Washington DC: Clearinghouse for ESL Literacy Education. (ERIC Document Reproduction Service No. ED-LE-98-04).

http://www.Englishclub.com/speaking./what-is speaking.htm

http://www.Mikundan.com/Portofolio/winstaru/WUContent/jo baids/aecr/Lakhpin.blogspot.com/2014

Hymes, D. (1972). Models of the Interaction of Language and Social Life, In Gumperz, J.J. \& Hymes, D (eds), Directions in Sociolinguistics: The Ethnography of Communication, New York: Holts Rinehart \& Winston, pp. 35-71.

Hymes, D. (1974) Foundation of Sociolinguistics: An Ethnographic Approach. Philadelphia: U of Pennsylvania.

Lambirth, A. (2005). Primary English Reflective Reader. SAGE Publications.

Moyles, J (1989). Just Playing? Buckingham: Open University Press.

Orwig, C (1999). Aspects of Communicative Competence. Extract from the Lingua links Library, version 3,5, published on CD-Room by SIL International.

Oxford Dictionary of English. Third Edition. (2005). Oxford University Press.

Sally, A. (2005). Drama: Engaging all learning Styles. In Proceedings 9th International INGED (Turkish English Education Association) International Conference, Economics and Technical University, Ankara Turkey.

Van Duzer, C. (1997). "Improving ESL learners' listening skills: At the workplace and beyond."Washington, DC: Project in Adult Immigrant Education and National Clearinghouse for ESL Literacy Education.

Zand-Vakili, E., Kashani, A. F., \& Tabandeh, F. (2012). The Analysis of Speech Events and Hymes'SPEAKING' Factors in the Comedy Television Series: 'Friends'. New 
Media and Mass Communication Journal. ISSN 2243267 (paper) Vol. 2, 2012. 